\title{
Lupus nephritis: clinicopathological study of 162 cases in Thailand
}

\author{
P PARICHATIKANOND, ND FRANCIS, ${ }^{*}$ P MALASIT, T LAOHAPAND, \\ S NIMMANNIT, L SINGCHOOVONG, S NILWARANGKUR, P CHRIRAWONG, \\ S VANICHAKARN
}

From the Department of Pathology and Renal Unit, Department of Medicine, Siriraj Hospital, Bangkok, Thailand, and the *Department of Experimental Pathology, St Mary's Hospital Medical School, London

SUMMARY One hundred and sixty two cases of lupus nephritis biopsied over three years in Thailand were studied. A pattern of clinical and histological renal disease very similar to that seen in the United States or Europe emerged.

The predominant histological type was World Health Organisation class IV (diffuse proliferative; $58.6 \%$ ). Patients with renal insufficiency (creatinine $\geqslant 2 \mathrm{mg} / 100 \mathrm{ml}$ ) or hypertension at the time of biopsy had a considerably worse three year survival. Certain features such as sclerotic glomeruli, tubular atrophy, and an interstitial mononuclear cell infiltrate were significantly associated with a worse outcome $(0.05>p>0.01)$, and patients who died with poor renal function had significantly higher chronicity scores than those in other groups $(p<0.05)$. These findings emphasise the importance of chronic renal damage in the morbidity and mortality of patients with lupus nephritis.

The number of patients with systemic lupus erythmatosus registered each year is 150-180, representing $3.3 \%$ of the total medical inpatients at the Siriraj Hospital. The renal unit admits $60-80$ such patients annually, and during the period covered by this study 162 patients out of 230 had clinical evidence of renal disease.

In the absence of any studies of this condition from Thailand it seemed initially that the degree of concomitant renal disease, both clinically and histologically, was more severe than we had thought. We therefore carried out detailed investigations to establish any clinicopathological or prognostic differences that might be seen when our study was compared with other series ${ }^{1-10}$ from areas of a much lower prevalence.

We report 162 patients with lupus nephritis who attended the renal unit, Siriraj Hospital, Bangkok, who underwent renal biopsy between January 1981 and December 1983, and who were analysed according to the World Health Organisation classification (Table 1). ${ }^{11}$ (These patients have now become part of a long term follow up study.

Accepted for publication 14 October 1985

\section{Patients and methods}

Of 1119 renal biopsies performed between January 1981 and December 1983, 180 were from 173 patients fulfilling four or more of the preliminary ${ }^{12}$ or revised, ${ }^{13}$ or both, American Rheumatism Association criteria for the diagnosis of systemic lupus erythmatosus. Eleven biopsies were inadequate resulting in 169 from 162 patients (154 new cases and eight repeat biopsies).

The female:male ratio was $154: 8$ (19:1) and mean age was $26 \cdot 6$ ((SD) 9.8 years) (range 6-66 years) at the time of biopsy.

In each case serological evidence of systemic lupus erythmatosus (LE preparation, ANF, anti-ds DNA) was sought as one of the criteria and was obtained in all but one case, in which six other criteria were fulfilled.

There was no obvious geographical bias among the population studied: Siriraj Hospital ( 750 beds) is one of six teaching hospitals in Bangkok (population 4.5 million) serving a large part of Bangkok as well as provincial cities all over Thailand.

\section{CLINICAL EVALUATION}

Renal function was classified by serum creatinine, and a concentration of $\geqslant 2 \mathrm{mg} / \mathrm{dl}$ was categorised as renal insufficiency. Patients were divided into those with 
Table 1 Histological patterns, age, sex, and pathological scores in renal biopsies from 162 patients with systemic lupus erythmatosus

\begin{tabular}{|c|c|c|c|c|c|c|c|c|}
\hline \multirow[t]{2}{*}{ WHO class $^{11}$} & \multicolumn{3}{|c|}{ Patients } & \multirow{2}{*}{$\begin{array}{l}\text { Age at biopsy } \\
\text { (years) mean (SD) }\end{array}$} & \multirow{2}{*}{$\frac{S e x}{F M}$} & \multicolumn{3}{|c|}{ Pathological scores (mean (SD)) } \\
\hline & No & Total & $\%$ & & & $\overline{\text { Activity }}$ & Chronicity & Total \\
\hline \multicolumn{9}{|l|}{ Normal glomeruli: } \\
\hline $\begin{array}{l}\text { No immune deposits } \\
\text { With immune deposits }\end{array}$ & 1 & 1 & 0.6 & 37 & 1:0 & $\mathbf{0}$ & $\mathbf{0}$ & 0 \\
\hline Mesangial: & & & & & & & & \\
\hline $\begin{array}{l}\text { Mild cellularity } \\
\text { Moderate cellularity }\end{array}$ & 29 & 29 & $17 \cdot 9$ & $27 \cdot 6(11 \cdot 4)$ & 28:1 & $1.9(1.0)$ & $1 \cdot 1(1 \cdot 4)$ & $3 \cdot 0(2 \cdot 2)$ \\
\hline \multicolumn{8}{|l|}{ Focal proliferative: } & \\
\hline $\begin{array}{l}\text { Sclerosing lesion } \\
\text { "Active" and sclerosing lesion }\end{array}$ & 4 & 16 & 9.9 & $25 \cdot 5(8 \cdot 6)$ & $15: 1$ & $4 \cdot 2(1 \cdot 8)$ & $1.9(1.5)$ & $6 \cdot 1(2 \cdot 5)$ \\
\hline \multicolumn{9}{|l|}{ Diffuse proliferative: } \\
\hline $\begin{array}{l}\text { Pure proliferation } \\
\text { "Active" lesion } \\
\text { Sclerosing lesion } \\
\text { "Active" and sclerosing lesion }\end{array}$ & $\begin{array}{r}9 \\
55 \\
25 \\
6\end{array}$ & 95 & $58 \cdot 6$ & $25.9(9 \cdot 8)$ & $90: 5$ & $8 \cdot 0(2 \cdot 4)$ & $3 \cdot 1(1 \cdot 9)$ & $11 \cdot 3(2 \cdot 9)$ \\
\hline \multicolumn{9}{|l|}{ Membranous: } \\
\hline $\begin{array}{l}\text { With feature of class II } \\
\text { With feature of class III* }\end{array}$ & $\begin{array}{r}11 \\
3\end{array}$ & 21 & $12 \cdot 9$ & $27 \cdot 2(8 \cdot 6)$ & $20: 1$ & $5 \cdot 7(2 \cdot 1)$ & $2 \cdot 1(1 \cdot 8)$ & $7 \cdot 8(3.5)$ \\
\hline $\begin{array}{l}\text { With feature of class IV* } \\
\text { Total }\end{array}$ & 6 & 162 & $100 \cdot 0$ & $26.4 \pm 9.8$ & $154: 8$ & & & \\
\hline
\end{tabular}

* May be classified as class III and IV. In this study if numerous or large subendothelial deposits, or both, or proliferation was severe, the biopsy was classified as class IV.

and without renal insufficiency at the time of biopsy.

For evaluation of outcome a change of more than one third of the serum creatinine was considered to be clinically important and on this basis patients were allocated into five groups at the end of the study: A better; $B$ no change; $C$ worse, or death from renal failure, or from another cause, but with a record of deteriorating renal function; $D$ death without a record of deteriorating renal function; $E$ lost to follow up. Patients in group B were reallocated if there had been a change in haematuria, $(+$ to - or - to +$)$ or by a change in proteinuria of more than $2+$.

Clinical definitions used in this study were: clinically important haematuria, $>5$ red blood cells/high power field; clinically important proteinuria, $\geqslant 1 \mathrm{~g} / 24$ hours; hypertension, diastolic blood pressure $>95 \mathrm{~mm} \mathrm{Hg}$ on two separate occasions, or a record of anti-hypertensive treatment.

Tissue was divided into three portions for light microscopy with immunoperoxidase staining (an established method), ${ }^{14}$ immunofluorescence, and high resolution light microscopy $(1 \mu \mathrm{m})$.

\section{EVALUATION OF BIOPSIES}

All cases had at least five glomeruli in sections embedded in paraffin and epoxy resin. Each biopsy was assessed independently by two observers (PP and NDF) and classified into one of the WHO classes. ${ }^{11}$ Cases with repeat biopsies were classified by the first one except in the eight cases coming to biopsy before
1981 for which no immunopathological studies were available.

A pathological scoring system ${ }^{4}$ was used, resulting in activity, chronicity, and total scores for each biopsy. Each feature was graded 0 to $3+(0=$ absent, $1+=<25 \%, 2+=25-75 \%, 3+=>75 \%)$. There was rarely a difference of greater than $1+$ for any feature among the observers. This supports the findings of others. ${ }^{615}$

\section{SEROLOGY}

ANF and anti ds-DNA were tested using standard methods. ${ }^{1617}$ Differences between each WHO class were compared using the Mann-Whitney test. Individual pathological features related to outcome were tested by the $\chi^{2}$ test and contingency table methods. Survival data were analysed by the life table method $^{18}$ and calculated from the time of biopsy.

\section{Results}

CLINICAL

Apart from renal disease, the most common presenting signs were skin rash, anaemia, and joint symptoms. Table 2 shows the clinical manifestations throughout the course of follow up. All patients had clinical renal disease, and the most common features were those related to skin and joints. Hypertension and anaemia were common complications, mostly from class IV patients. Disease of the central nervous 
Table 2 Clinical manifestations throughout follow up period of 162 patients with systemic lupus erythmatosus

\begin{tabular}{|c|c|c|c|c|c|c|c|}
\hline & \multicolumn{5}{|c|}{ WHO class } & \multicolumn{2}{|l|}{ Total } \\
\hline & $I$ & II & $I I I$ & $I V$ & $V$ & Case & $\%$ \\
\hline $\begin{array}{l}\text { No of patients } \\
\text { Skin rash } \\
\text { Joint symptoms } \\
\text { Hypertension } \\
\text { Anaemia } \\
\text { Infection } \\
\text { Oral ulcer } \\
\text { Vasculitis } \\
\text { CNS symptoms } \\
\text { Serositis } \\
\text { Raynaud's phenomenon } \\
\text { Ocular signs } \\
\text { Avascular necrosis of femur }\end{array}$ & $\begin{array}{l}1 \\
1\end{array}$ & $\begin{array}{r}29 \\
19 \\
18 \\
8 \\
13 \\
10 \\
7 \\
9 \\
3 \\
3 \\
4 \\
1\end{array}$ & $\begin{array}{r}16 \\
12 \\
14 \\
5 \\
6 \\
4 \\
9 \\
7 \\
2 \\
1 \\
1 \\
1 \\
1\end{array}$ & $\begin{array}{r}95 \\
59 \\
60 \\
57 \\
52 \\
27 \\
19 \\
14 \\
18 \\
16 \\
7 \\
6 \\
2\end{array}$ & $\begin{array}{r}21 \\
15 \\
11 \\
9 \\
6 \\
5 \\
2 \\
5 \\
4 \\
3 \\
3 \\
1\end{array}$ & $\begin{array}{r}162 \\
106 \\
103 \\
79 \\
77 \\
46 \\
37 \\
35 \\
27 \\
23 \\
15 \\
9 \\
3\end{array}$ & $\begin{array}{r}100 \cdot 0 \\
65 \cdot 4 \\
63 \cdot 6 \\
48 \cdot 8 \\
47 \cdot 5 \\
28 \cdot 4 \\
22 \cdot 8 \\
21 \cdot 6 \\
16 \cdot 7 \\
14 \cdot 2 \\
9 \cdot 3 \\
5 \cdot 6 \\
1.9\end{array}$ \\
\hline
\end{tabular}

system was not a predominant feature in any WHO class. Infections were common and often multiple. There was no clear age difference between patients from WHO classes.

Evidence of renal disease, obtained from referral information, histories, and recorded data at presentation, comprised oedema $(72 \cdot 3 \%)$, proteinuria $(28 \cdot 4 \%)$, and gross haematuria $(14 \cdot 2 \%)$.

\section{PATHOLOGY}

Table 1 shows the distribution of age, sex, and pathological scores within each group. Table 3 shows some specific features at the time of biopsy, the most striking of which was the high proportion of patients with haematuria and those in classes IV and V with proteinuria in the nephrotic range.

Mean activity scores between each class, chronicity scores between classes II and V, and total pathological scores between each class except III and $\mathrm{V}$ were all significantly different $(\mathrm{p}<0.01)$. The remainder were marginally significant $(0.05>p>$ $0 \cdot 01$ ). Class IV patients had the highest mean scores.

Adequate material was available for immunofluorescence or immunoperoxidase studies, or both, in 134 cases. Most were positive for IgG (130), IgA (129), IgM (128), and C3 (131). Sixty eight of 130 patients were positive for fibrinogen and 49 of 60 of those tested were positive for $\mathrm{C} 4$. IgG was the predominant immunoglobulin in 97 cases.

\section{SEROLOGY}

LE cell preparation, ANF and anti ds-DNA were positive in $55.4 \%, 91.9 \%$, and $62.1 \%$, respectively, of the patients tested. In all but one of the patients whose test for ANF was negative or not recorded, the LE cell preparation and anti ds-DNA were positive.

\section{FOLLOW UP (TABLE 4)}

Fourteen patients were lost to follow up. The remaining 148 were followed up for two to 44 months (mean $14.9(10.0)$ ) after biopsy. Thirty six $(24 \%)$ showed no change, $69(47 \%)$ improved, and $19(13 \%)$ deteriorated. Follow up intervals varied widely within each class, and no statistical analysis was attempted.

Twenty four (16\%) patients died, 17 of whom were in class IV. Infection was the cause of death in nearly half of them. Renal failure was an important cause of death and occurred only in class IV patients. Survival curves from the time of biopsy seen in Fig. 1 show that class IV patients had the worst three year survival.

\section{REPEAT BIOPSIES}

Thirteen cases had more than one adequate biopsy, resulting in 30 biopsies for analysis. Six cases showed no change in WHO class. Three cases changed from class IV to II, two from III to IV, one from II to IV, and one from IV to $\mathrm{V}$.

Table 3 Renal findings at time of biopsy

\begin{tabular}{|c|c|c|c|c|c|c|c|}
\hline & \multicolumn{5}{|c|}{ WHO class } & \multicolumn{2}{|c|}{ Total } \\
\hline & $I$ & II & $I I I$ & $I V$ & $V$ & $N o$ & $\%$ \\
\hline $\begin{array}{l}\text { No of patients } \\
\text { Hypertension } \\
\text { Haematuria ( }>5 \mathrm{rbcs} \text { hpf) } \\
\text { Proteinuria } 1-3 \mathrm{~g} / 24 \text { hours } \\
\qquad>3 \mathrm{~g} / 24 \text { hours } \\
24 \text { hour protein }(\mathrm{g})(\text { mean }(\mathrm{SD})) \\
\text { Creatinine } \mathrm{mg} / 100 \mathrm{ml} \text { (mean (SD)) }\end{array}$ & $\begin{array}{l}1 \\
1\end{array}$ & $\begin{array}{l}29 \\
4 \\
5 \\
1 \\
2 \\
0.7(1 \cdot 4) \\
1.0(0.4)\end{array}$ & $\begin{array}{l}16 \\
4 \\
9 \\
7 \\
3 \\
1 \cdot 7(1 \cdot 4) \\
1 \cdot 4(0 \cdot 7)\end{array}$ & $\begin{array}{l}95 \\
51 \\
73 \\
16 \\
58 \\
5 \cdot 28(3 \cdot 2) \\
2 \cdot 1(2 \cdot 0)\end{array}$ & $\begin{array}{l}21 \\
4 \\
5 \\
4 \\
15 \\
5 \cdot 4(4 \cdot 3) \\
1 \cdot 3(0 \cdot 8)\end{array}$ & $\begin{array}{r}162 \\
63 \\
93 \\
28 \\
78\end{array}$ & $\begin{array}{r}100.0 \\
38.9 \\
57.4 \\
17.3 \\
48.1\end{array}$ \\
\hline
\end{tabular}




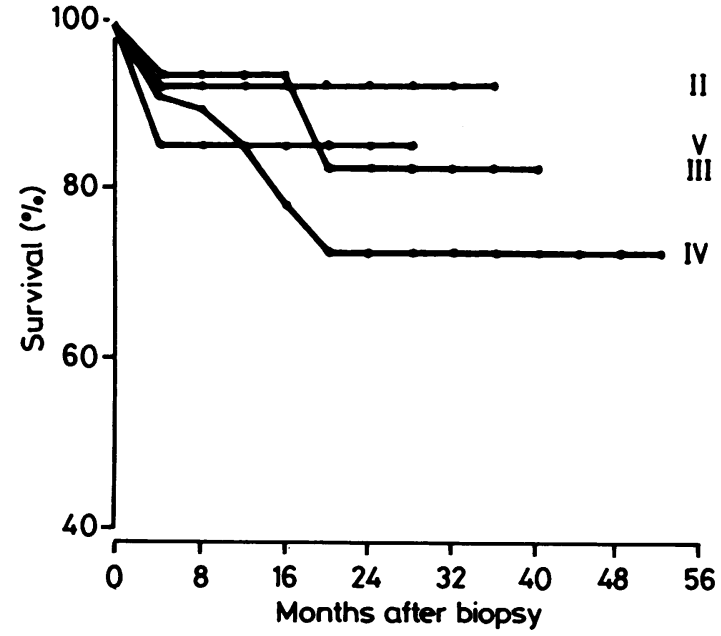

Fig. 1 Survival of patients in $W H O$ biopsy class $I I, I I I, I V$, and $V$.

\section{ANALYSIS}

Chronicity scores of the eight patients who died as a result of renal failure (5) or who had renal failure at the time of death from another cause (3) were significantly higher than those of the other outcome groups ( $p<0.05$, Table 4$)$. Division of patients into those with a total pathological score of $<8$ and those with $>8$ showed only a slightly worse (insignificant) three year survival of the second group $(89.6 \% v$ $95 \cdot 1 \%$ ). Within each WHO class there was no significant difference between the pathological scores of the different outcome groups.

The presence of more than $25 \%$ of the following features was associated with a worse outcome: sclerotic glomeruli $(\mathrm{p}=0.014)$, tubular atrophy $(\mathrm{p}=$ $0.036)$, and interstitial mononuclear cell infiltration ( $p$ $=0.011)$. Patients who had "renal insufficiency" (33 cases) or hypertension (63 cases) at the time of biopsy had a significantly poorer three year survival $(45.4 \% v$ $83.5 \%, \mathrm{p}<0.001 ; 65.5 \%$ v 88.4\%, $0.001<\mathrm{p}<0.01$, respectively) (Figs. $2 \mathrm{a}$ and $\mathrm{b}$ ).

Despite careful searching only two cases with definite capillary fibrin thrombi and one case with vasculitis were found. Haematoxyphil bodies were noted in only six cases $(3.6 \%)$; four in class IV and two in class III, all in areas of necrosis.

\section{Discussion}

Our study shows that systemic lupus erythmatosus is unusually common and that a large proportion of the patients seen at this hospital present with renal disease. The preselection of patients for renal biopsy, however, and the fact that this is a referral centre means conclusions drawn about this group do not necessarily apply to all cases of systemic lupus erythmatosus in Thailand.

The unusually high female to male ratio $(19: 1)$ is, in part, fortuitous. A previous report from Thailand ${ }^{19}$ showed a ratio close to that reported in the United States and United Kingdom of 10:1, but the combined figures from 1978-1983 show a ratio of 14:1 (397:28). The reason for this higher preponderance among women is unclear.

Frank $^{20}$ drew attention to the higher incidence of systemic lupus erythmatosus among the Chinese in Malaysia, and two other studies indicated a high prevalence of the disease among Chinese in Hawaii ${ }^{21}$ and a higher mortality among Chinese with systemic lupus erythmatosus in the United States. ${ }^{22}$ It is extremely difficult to analyse the ethnic origin of our patients, but intermarriage between Thai and Chinese is common.

The main conclusion of our study is that the pattern of renal disease and clinical presentation is

Table 4 Follow up data

\begin{tabular}{|c|c|c|c|c|c|c|c|c|c|}
\hline & \multicolumn{5}{|c|}{ WHO class } & \multirow{2}{*}{$\begin{array}{l}\text { Total } \\
\text { Total }\end{array}$} & \multicolumn{3}{|c|}{ Pathological score } \\
\hline & $\vec{I}$ & $I I$ & III & IV & $V$ & & Activity & Chronicity & Total \\
\hline \multirow{6}{*}{$\begin{array}{l}\text { No of patients: } \\
\text { Interval (biopsy to end of study } \\
\text { in months) (mean (SD)) } \\
\text { Outcome: } \\
\text { Improvement } \\
\text { No change } \\
\text { Deterioration } \\
\text { Death from: } \\
\text { i Renal failure } \\
\text { ii Heart failure } \\
\text { iii Infection } \\
\text { iv CNS } \\
\text { v Unknown } \\
\text { Deaths due to and associated with renal } \\
\text { failure }\end{array}$} & 1 & 28 & 16 & 84 & 19 & 148 & & & \\
\hline & 18 & $19 \cdot 1(17 \cdot 3)$ & $15 \cdot 1(10 \cdot 6)$ & $16 \cdot 3(13 \cdot 5)$ & $11 \cdot 5(7 \cdot 5)$ & & & & \\
\hline & 1 & $\begin{array}{r}13 \\
8 \\
5\end{array}$ & $\begin{array}{l}7 \\
4 \\
3\end{array}$ & $\begin{array}{r}39 \\
20 \\
8\end{array}$ & $\begin{array}{r}10 \\
3 \\
3\end{array}$ & $\begin{array}{l}69 \\
36 \\
19\end{array}$ & $\begin{array}{l}6 \cdot 2(3 \cdot 3) \\
5.9(3 \cdot 5) \\
5 \cdot 1(3 \cdot 1)\end{array}$ & $\begin{array}{l}2.4(1.8) \\
2.1(1.6) \\
2.5(2.1)\end{array}$ & $\begin{array}{l}8 \cdot 6(4 \cdot 3) \\
8 \cdot 0(4 \cdot 6) \\
7 \cdot 6(4 \cdot 4)\end{array}$ \\
\hline & & 1 & 1 & $\begin{array}{l}5 \\
1(1)^{*} \\
7(2)^{*}\end{array}$ & $\begin{array}{l}2 \\
1\end{array}$ & $\begin{array}{l}5 \\
1(1)^{*} \\
11(2)^{*} \\
1\end{array}$ & & & \\
\hline & & 1 & 1 & 4 & & 6 & & & \\
\hline & & & & 8 & & 8 & $7 \cdot 4(2 \cdot 1)$ & $5(3 \cdot 2)$ & $12.4(3.6)$ \\
\hline
\end{tabular}

*Numbers in parentheses indicate No of patients who had renal failure at the time of death but whose death was not caused by renal failure. 

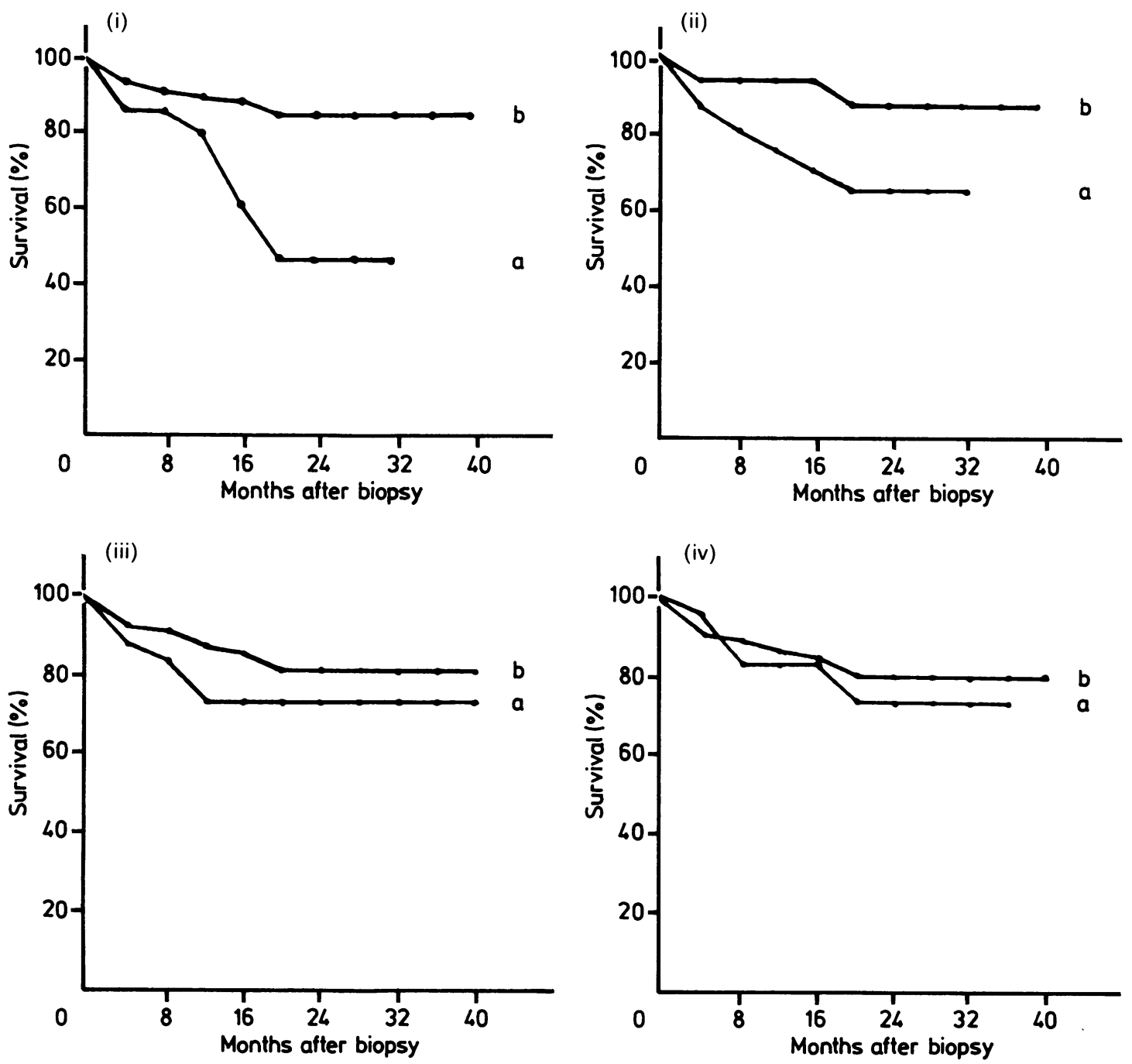

Fig. 2 Survival of patients: $i$ ) with (a) and without (b) renal insufficiency; $i$ ) with (a) and without (b) hypertension; iii) with crescents of more $(a)$ and less $(b)$ than $25 \%$ of the glomeruli; and iv) with (a) and without (b) hyaline thrombi.

very similar to that seen in the United States or United Kingdom. We found a $10 \%$ higher proportion of patients in WHO class IV and a $9 \%$ lower proportion of patients in class II and III combined, when compared with combined data presented by Hill; ${ }^{23}$ these differences are not significant, which is of importance in the light of a recent report ${ }^{24}$ in which 27 Korean patients were found to have a significantly higher percentage of class IV $(\mathbf{7 7 \cdot 8 \% )}$ ) and fewer class VII cases. This apparent discrepancy could be due to the relatively small number of Korean patients, or it could reflect a difference in the pattern of renal disease in Thailand and Korea. Compared with other series $^{1357}$ our cases show similar age distribution, clinical manifestations of systemic lupus erythmatosus, renal presentation, and prevalence of hypertension.

Our follow up period was short, but causes of death are similar to those discussed in previous reports, ${ }^{5-7}$ with infections being the commonest and renal failure the second commonest cause. Our three year survival rates were close to those of Appel et al ${ }^{1}$ in all classes; class IV patients showed the worst survival, which supports the view that histological class is prognostically important.

Using the scoring system, we found class IV 
patients had significantly higher mean pathological scores (activity, chronicity, and total) as did Balow et $a l^{4}$ and Austin et $a l^{5}$ but the overlap of scores between classes meant that the score alone was not a good predictor of class or survival.

Our findings, although not directly comparable, do not support Kaslow's2 ${ }^{22}$ findings of higher mortality in oriental patients with systemic lupus erythmatosus. Our follow up period was short, however, and we only looked at patients with lupus nephropathy, while Kaslow's data were taken from death certificate records.

Assessing indicators of outcome, we found that renal insufficiency and hypertension at the time of biopsy were associated with a worse three year survival, and a clinically important presence of sclerotic glomeruli: tubular atrophy, and an interstitial mononuclear cell infiltrate were associated with a worse outcome. In addition, patients who died with deteriorating renal function had a considerably higher chronicity score than other outcome groups. These findings emphasise the importance of chronic renal damage in lupus nephritis.

The total pathological score was not associated with deteriorating renal function or development of renal failure, unlike Balow's study, ${ }^{4}$ and important differences between scores of each outcome group within each class were not found.

In view of previous authors weighting their scoring systems ${ }^{825}$ for cellular crescents we were surprised to find no association between crescents and a worse outcome and no important difference in the three year survival between these patients. It will be interesting to see if longer term follow up shows any such association, as patients may have an initially good response to aggressive treatment, which may delay the decline in renal function for as much as three or four years. A recent paper by Austin et al ${ }^{26}$ reported that after four years of follow up cellular crescents predicted a decline in renal function: a further report $^{27}$ identified crescentic glomerulonephritis as the most common underlying pathology of acute deterioration in renal function.

We are indebted to the Wellcome Trust for their support of this project by providing a generous grant to Dr N Francis as a research fellow and for their continuing support of Drs Malasit and Laohapand.

We are indebted to Miss P Chaiyanon, S Mingkum, $\mathrm{K}$ Srisuk, and $\mathbf{S}$ Khuansuwan for their expert technical help and Mr V Supattee for the illustrations.

We thank Mrs P Dodi and Miss P Iap-Uan for secretarial help. We also sincerely thank Professor KA Porter for his help, encouragement, and support of this study.

\section{References}

${ }^{1}$ Appel GB, Silva FG, Pirani CL, Meltzer JI, Estes D. Renal involvement in systemic lupus erythematosus (SLE): a study of 56 patients emphasising histological classification. Medicine 1978;57:371-410.

${ }^{2}$ Baldwin DS, Lowenstein J, Rothfield NF, Gallo G, McCluskey RT. The clinical course of the proliferative and membranous forms of lupus nephritis. Ann Intern Med 1970;73:929-42.

${ }^{3}$ Baldwin DS, Gluck MC, Lowenstein J, Gallo GR. Lupus nephritis: clinical course as related to morphological forms and their transitions. Am J Med 1977;62:12-30.

${ }^{4}$ Balow JE. Clinicopathologic correlations in lupus nephritis. Systemic lupus erythematosus: evolving concepts. Ann Intern Med 1979;91:596-9.

${ }^{5}$ Cameron JS, Turner DR, Ogg CS, et al. Systemic lupus with nephritis: a long term study. $Q J$ Med 1979;48:1-24.

${ }^{6}$ Fish AJ, Blau EB, Westberg NG, Burke BA, Vernier RL, Michael AF. Systemic lupus erythematosus within the first two decades of life. Am J Med 1977;62:99-117.

${ }^{7}$ Lee P, Urowitz MB, Bookman AAM, et al. Systemic lupus erythematosus: a review of 110 cases with reference to nephritis, the nervous system, infections, aseptic necrosis and prognosis. Q J Med 1977;46:1-32.

${ }^{8}$ Morel-Maroger LJ, Mery J-PH, Droz D, et al. The course of lupus nephritis: contribution of serial renal biopsy. Adv Nephrol 1976;6:79-118.

${ }^{9}$ Sinniah R, Feng PH. Lupus nephritis: correlation between light, electron microscopic and immunofluorescent findings and renal function. Clin Nephrol 1976;6:340-51.

${ }^{10}$ Wallace DJ, Podell TE, Weiner JM, et al. Lupus nephritis: experience with 230 patients in private practice from 1960-1980. Am J Med 1982;72:209-20.

${ }^{11}$ Churg J, Sobin LH. Renal disease: classification and atlas of glomerular diseases. Tokyo: Igaku-Shoin, 1982:127-49.

${ }^{12}$ Cohen AS, Reynolds WE, Franklin EC, et al. Preliminary criteria for the classification of systemic lupus erythematosus. Bull Rheum Dis 1971;21:643-8.

${ }^{13}$ Tan EM, Cohen AS, Fries JF, et al. The 1982 revised criteria for the classification of systemic lupus erythematosus. Arthritis and Rheumatology 1982;25:1271-7.

${ }^{14}$ MacIver AG, Mepham BL. Immunoperoxidase techniques in human renal biopsy. Histopathology 1982;6:249-67.

${ }^{15}$ Pirani CL, Pollack VE, Schwartz FD. The reproducibility of semiquantitative analyses of renal histology. Nephron 1964;1:230-7.

${ }^{16}$ Johnson GD, Dorling J. Immunofluorescence and immunoperoxidase techniques. In: Thompson RA, ed. Techniques in clinical immunology. 2nd ed. Oxford: Blackwell Scientific Publications, 1981:122-4.

${ }^{17}$ Aarden LA, Grott ER, Feltkamp TEW. Immunology of DNA. III. Crithidia luciliae, a simple substrate for the determination of anti-ds-DNA with the immunofluorescent technique. Ann NY Acad Sci 1975;254:505-13.

${ }^{18}$ Rimm AA, Hartz AT, Kalbfleisch JH, Anderson JA, Hoffman RG. Basic biostatistics in medicine and epidemiology. New York: Appleton-Century-Croft, 1980:306-14.

${ }^{19}$ Chirawong P, Nimmannit S, Vanichakarn S, Singchoovong L, Nilwarangkur S. Lupus nephritis: an analysis of treatments in 163 cases. Siriraj Hospital Gazette 1981;33:145-56.

${ }^{20}$ Frank AO. Apparent predisposition to systemic lupus erythematosus in Chinese patients in west Malaysia. Ann Rheum Dis 1980;39:266-9.

${ }^{21}$ Serdula MK, Rhoads GC. Frequency of systemic lupus erythematosus in different ethnic groups in Hawaii. Arthritis Rheum 1979;22:328-33.

${ }^{22}$ Kaslow RA. High rate of deaths caused by systemic lupus erythematosus among US residents of Asian descent. Arthritis Rheum 1982;25:414-8.

${ }^{23} \mathrm{Hill}$ GS. Systemic lupus erythematosus and mixed connective tissue diseases. In: Heptinstall RH, ed. Pathology of the kidney. 3rd ed. 
Boston: Little Brown and Co, 1983:839-936.

${ }^{24}$ Lee HS, Spargo BH. A renal biopsy study of lupus nephropathy in the United States and Korea. Am J Kidney Dis 1985;5:242-50.

${ }^{25}$ Austin HA, Muenz LR, Joyce KM, et al. Prognostic factors in lupus nephritis: contribution of renal histological data. Am J Med 1983;75:382-91.

${ }^{26}$ Austin HA, Muenz LR, Joyce KM, Antonovych TA, Balow JE. Diffuse proliferative lupus nephritis: identification of specific pathological features affecting outcome. Kidney Int
1984;25:689-95.

${ }^{27}$ Yeung CK, Ng WL, Wong WS, Wong KL, Chan MK. Acute deterioration in renal function in systemic lupus erythematosus. $Q J$ Med 1985;219:393-402.

Requests for reprints to: Dr P Parichatikanond, Department of Pathology, Siriraj Hospital, Bangkok 10700 , Thailand. 